\title{
Bologna Process in Ukraine: The Decade Anniversary
}

\author{
Sofiya Nikolaeva \\ Kyiv National Linguistic University \\ Department of the Foreign Language Teaching Methodology \\ 73, Velyka Vasylkivska St., Kyiv, Ukraine, 03680 \\ e-mail: nikolaeva.su@yandex.ru
}

Keywords: Bologna Process, Higher Education Area, Ukraine, quality assurance, degree structure, promotion of mobility, system of credits, lifelong learning.

\begin{abstract}
The article presents the results of the analysis of achievements an hortcom Ukraine in joining the European Higher Education Area. For the research imnem the enyear period of the Bologna process in Ukraine is divided into four stage (steps): 1 from Bergen to London; step 2 - from London to Leuven; step 3 - from Ley en to 9 chare step 4 from Bucharest to Yerevan. Within each of the stages the appropripe gation nethods are used. In general, the following techniques are applied: review aocun and publications; survey of students, $\mathrm{PhD}$ students and professors; observatio the educ al process and reflection; testing of bachelors, masters and $\mathrm{PhD}$ students, da collo on; over rew of the official sites of Ukrainian universities. For each of the stages ident pros an ny are considered. It has been concluded that per decade Ukraine has achieve a lot, but many of the key issues need solution.
\end{abstract}

\section{INTRODUCTION}

Ukraine joined the Bologna Process in 205 an Dergen Conference and signed the Bergen Declaration. That it has committed itself to defin the grection and contours of the reform of the system of higher education. Ukraine djusted tself to Western European trends, and as one of its most important steps it has cidec to adop he structural model and accept the Bologna Declaration and the basic princile clesen-up conferences.

As it is laid down o the Bol Process official site, The Bologna Declaration in 1999 set out a vision for $2 \%$ of an in ationally competitive and attractive European Higher Education Area (EHE wh higher education institutions can fulfill their diverse missions in the knowledge soci cry, and who stydents can find the best suited educational pathways. As the main objective $Q$ the B logna Pro,ess since its inception in 1999, the EHEA was meant to ensure more comparaon ov atrble and coherent systems of higher education in Europe. Between 19992010, all the effor the Jogna Process members were targeted to creating the EHEA, that became can with th adapest-Vienna Declaration of March, 2010. According to the Bologna Proce locul ents the ext decade (2010-2020) will be aimed at consolidating the EHEA.

W. Ine became a Bologna Process participating country in 2005. This year, 2015, is the ten. nniversary (a decade). The ten-year period of the European recommendations implementatio should be divided, from our point of view, into several stages (steps) according to the conferences held and communiqué adopted: step 1 - from Bergen to London; step 2 - from London to Leuven; step 3 - from Leuven to Bucharest; step 4 - from Bucharest to Yerevan.

\section{PROBLEM STATEMENT}

This paper analyses the impact of the Bologna Process reforms in Ukrainian higher education under these steps. It aims to find out if the recommendations already implemented and those under realization have been successful, without considering political and economic problems. Look at each of the steps closer. 


\section{Step 1 - from Bergen (2005) to London (2007)}

The main method of investigation used at the stage is documents and publications [1] review. With regard to Ukraine it is rightly to speak about two phases of the Bologna Process recommendations implementation within this step: before 2005 (preparatory) and after (basic). Consider these phases in more detail.

\section{$\checkmark$ The preparatory phase $(2002-2005)$}

First of all, it is necessary to call to memory, what was happening in the Bologna Process during that period of time. The Sorbonne declaration of 25th of May 1998 emphasized the creation of the European area of higher education as a key way to promote citizens' employability and the Continent's overall development [2]. A year later the Bolo na Decm tion of 19th of June 1999 was adopted. The European Ministers of Education enga to reach the short term, and in any case within the first decade of the third millennium, the ollow objec ves, which they considered to be of primary relevance in order to establish the Luronean an of inger education and to promote the European system of higher education rld-y a don a system of easily readable and comparable degrees; adoption of a sy ntially ased on two main cycles, undergraduate and graduate; establishment of a sy $\mathrm{em}$ of cro $-\mathrm{such}$ as in the European Credit Transfer System (ECTS); promotion of mob ity overcom obstacles to the effective exercise of free movement; promotion of Europ coop ion in quality assurance; promotion of the necessary European dimensions in hig er eaucation $A$ wo years after signing the Bologna Declaration, in 2001, European Ministers $r$ et in Prague in onder to review the progress achieved and to set directions and priorities for the coming ye $\mathrm{rs}$ of the process. Ministers reaffirmed their commitment to the objective of estab ing the Faropean Higher Education Area by 2010. In Prague Communiqué on 19th May 20 Murther process as follows: adoption of a system of eas 1 le and comparable degrees and of a system essentially based on two main cycles; establishn ent $\mathrm{fta}_{\text {a }}$ stem of credits; promotion of mobility, European cooperation in quality ance, $t$ European dimensions in higher education. Furthermore, Ministers emphasiz a th followi ypoints: lifelong learning, higher education institutions and students, promotin.

On 19th of September 2033 , tsters responsible for higher education from 33 European countries met in Berlin $\mathrm{i}$ rer to re progress achieved and to set priorities and new objectives for the com $g$ with a view to speeding up the realization of the EHEA. The fundamental conside tons, pri les, and priorities were concretized and agreed: national quality assurance system shou'd be desig d by 2005; the implementation of the two-cycle system should be started by 5 onity of students and academic and administrative staff is the basis for establishing a EH the E $\mathrm{ES}$ becomes not only a transfer but also an accumulation system; every sty radua a from 2005 should receive the Diploma Supplement automatically and free 9 charg, additio a modules, courses and curricula with European content, orientation or organiz o developed; integrated study programs and joint degrees at first, second and third leve, being worked out; qualifications frameworks for the EHEA are to encompass the wide range of cxible learning paths, opportunities and techniques and to make appropriate use of the ECTS creaits.

As a whole, the basic provisions of the Berlin communiqué "Realizing the European Higher Education Area" were considering objectives expansion, in terms of union the EHEA relations into the European Research Area, as well as measures to facilitate the quality education obtaining. Another important issue discussed in the Communiqué was the creation of new structures to support the process initiated within the framework of two ministerial conferences. In this Communique the ministers also agreed that appropriate national structures in each participating country should be set up [5].

Review of the state documents and publications of the time allows speaking about the following. 


\section{The major achievements in Ukraine within the preparatory phase}

Ukraine views its development within the context of integration into Europe, orienting itself to the fundamental values of the Western culture, first of all, parliamentarism, human rights, liberalization, freedom of travel, equal access to quality education of any level etc. Ukraine is striving to be a full-fledged participant to the process of European integration.

The legal basis for reforming higher education during the preparatory stage was the 2002 Law on Higher Education [6] aimed to facilitate the processes of democratizing relationships at all levels of education functioning. It delineated the powers and rights of all subjects of higher education, the principles of the higher education institutions autonomy, governed relations in the spheres of teaching, acculturation, and professional training, and created conditions for persan-1ity selfrealization, catering for the society need in qualified specialists. The Associatio of Rt s of Ukrainian Universities supported the approaches to the accession of Ukraine to th ologna pr ess. In 2004, the Ministry of Education and Science of Ukraine approved and in the programme "The System of Higher Education in Ukraine and the Bologna P ocess" [7]. p-p cority approaches to accession of Ukraine to the Bologna process were videly iscuss at the international scientific-practice conferences in the country regions vith amified network of universities in Kyiv, Dnipropetrovsk, Kharkiv, and Lviv. Besid s, the La "On Research and Technical-Scientific Activities" [8], and executive acts by the $\mathrm{Pr}$ sh and the of ministers in the sphere of higher education were adopted. The impleme ation the above-mentioned Laws was obligatory for all higher education institutions.

In addition, for implementing the ideas of the Bo gna declaration, 2ne Ministry of Education and Science of Ukraine approved the Action Progran which inco porated activities till 2005. In particular, as well as to the main requirements of the $\mathrm{L}$ gna Dec aration implementation and the Berlin Communiqué of the Ministers of Ee uation on countries the following was planned:

- to improve the quality of education monitorin sy ston means of implementing the effective
mechanism of educational institution pulic rating - to expand the use of expert and te ang thods o knowledge and competence assessment;

- to disseminate to the public on

- to create data base of the can tr progums of national and foreign universities with the purpose of their further ncordance assessment in the process of national educational accreditation [9].

Thus, as it can leen fr what has been said, in Ukraine a little was done up to 2005 but the foundation wa laid down.

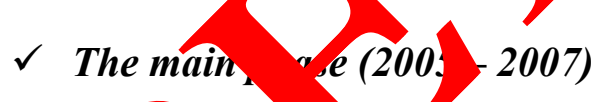
Educ, $\mathrm{w}$ ch took slace in Bergen, 19-20 May 2005. The Ministers met for a mid-term review and for 19 gom and priorities towards 2010. In Bergen Communiqué "The European Higher Education - Achieving the Goals", which was signed by the Minister of Education and Science of 4 raine, in short the following was underlined: the Ministers are to continue and intensify their efforts to establish the EHEA; the two-cycle degree system is being implemented on a large scale, with more than half of the students being enrolled in it; the development of national and European frameworks for qualifications is an opportunity to further embed lifelong learning in higher education; Doctoral level qualifications need to be fully aligned with the EHEA overarching framework for qualifications using the outcomes-based approach; appropriate conditions for students so that they can complete their studies without obstacles related to their social and economic background are needed; mobility of students and staff among all participating countries remains one of the key objectives of the Bologna Process; stocktaking is to be based on the appropriate methodology and to continue in the fields of the degree system, quality assurance and recognition of degrees and study periods [10]. 


\section{The major achievements in Ukraine within the main phase}

Reviewing the state documents, scientists' publications [11], findings of students and professors surveying as well as our personal experience allow us to speak about the next.

During 2005-2007 the important steps in realization of the Bologna Process regulations were implemented in the system of higher education of Ukraine; the Action Plan of their implementation till 2010 was developed. In 2006, according to the instruction of the Ministry of Education and Science the ministerial Bologna Follow Up working group and the National Team of Bologna Promoters interagency working group consisting of the leading universities specialists were established. They participated in training seminars on actual problems in higher education in European Education Area and further organized the training seminars in Ukraine on bacinissues of quality assurance, three-cycle system, recognition of degrees and study periods.

Ukrainian Council of Students, organized within the Ministry of Educat and Scien of Ukraine, became the candidate to the members of European Students' Unin (E. Durin the 2006/07 academic year almost all the universities established the ECTS.

The corresponding sets of the innovative legislative documents reco yenda ns were carried out; a draft of the Diploma Supplement and its implementati pi are we claborated. Two seminars concerning the convergence problems on the wa to EHE nitia ed by Magna Charta Council were held in 2006. The contacts with the Eur p Union wy groups were established [12].

\section{Main challenges for higher education in Ukraine till 207}

Comparative analysis of the Bergen Comm iqué re ommendations and the real achievements of Ukraine in the field of entry to EHEA conds for the conclusion that until 2007 it was desirable to solve the following ke,

- to elaborate the standards and guidelines fo grality ssurance as proposed in the European Association for Quality Assurance in $W^{\circ}$ her Educ tion (ENQA) report;

- to design the national framework for $\mathrm{q}$ lificatio

- to award and recognize joint $d \mathrm{eg}$ ir lodino 2 the doctorate level;

- to create opportunities for rexble rning paths in higher education, including procedures for the recognition of prior 1

- to improve the Bacher rs en yment - graduates of the first cycle;

- to increase the stur s and sta obility among participating countries;

- to extend the so cial her educa on institutions partnership with employers, citizens and public associations an voly in the decision elaboration process on higher education issues.

To summarn that ha been said above, it is reasonable to assert that during the reviewed period so the the th al and practical issues were resolved, but a significant part waited for its imple ntatic 1 .

Step 2 - fh London (2007) to Leuven (2009)

The research methods used at the stage are: review of documents and publications, survey of students and professors, observation of the educational process and reflection.

The Ministers responsible for Higher Education in the countries participating in the Bologna Process met in London on 18th of May 2007. In London Communiqué "Towards the European Higher Education Area: responding to challenges in a globalized world" it was emphasized that developments over the last two years had brought a significant step closer to the realization of the EHEA. It was stated that building on the rich and diverse European cultural heritage, an EHEA based on institutional autonomy, academic freedom, equal opportunities and democratic principles would facilitate mobility, increase employability and strengthen Europe's attractiveness and competitiveness. 
Action priorities for 2009 were broadened: promoting at national level the mobility of students and staff, including measures for future evaluation: developing national strategies and policies for the social dimension, including action plans and measures to evaluate their effectiveness; developing comparable and reliable indicators and data to measure progress towards the overall objective for the social dimension and student and staff mobility in all Bologna countries; improving employability in relation to each of the three-cycle degree system as well as in the context of lifelong learning; further developing of the qualitative analysis in stocktaking, particularly in relation to mobility, the Bologna Process in a global context and the social dimension [13].

\section{The major achievements in Ukraine}

The results of the collected data analysis have been generalized below.

Beginning from London 2007 a number of main developments relating took place in the system of higher education of Ukraine [9; 12]. An Action Pla a ality assurance for higher education of Ukraine and its integration into $\mathrm{e} \mathrm{Eu}$ zean a d world educational community for the period until 2010 was approved by he of the Ministry of Education and Science of Ukraine No.162 of July 13, 2007. A d aft of the w Ukraine "On Amendments to the Law of Ukraine on Higher Education" was ee ped accor to the Bologna provisions and recommendations. A system of ranking the riona rer education institutions (HEIs) was implemented in September 2007. Ukraine octane a go Mental member of the European Quality Assurance Register (EQAR) in Apr 2008. Ukrainiap Association of Student Self-government (UASS) became a member of ESL n Decembe 2007. Under the order of the Ministry of Education and Science of Ukraine No.60 July $03 / 2008$ a working group on the development of the National Qualification Framem 2 F) for higher education was established. Consultations on the designing it sevel descriptors, credit ranges were held. The two-cycle system was implemented at al hig ace ation institutions except for training students in the fields of medicine and veter ary medicine. Instruments of the third cycle implantation were elaborated. A sto e tar t resear and technical and social program "Research at Universities" for 2008-2012 w2 veld ned. Funang for doctoral students was provided by the state budget. All qualificatio f o irst gure gave access to several programs of the second cycle; all qualifications of second g gave access to at least one program of the third cycle. The employment data fo (gra tes of all) ycles in the 2007/08 academic year increased: Bachelors - to $14.4 \%$, Masters to $57 \%$.

As we can se, achievemen, of Ukraine in joining the EHEA were significant, but some of the London Cor unigr secammendations remained unfulfilled.

\section{Main cha" es for ver education in Ukraine till 2009}

omy rison of the London Communiqué provisions and our research results leads to the conclusio vat tic main challenges at the next stage for Ukraine are the following:

- to develop $\mathrm{YQF}$ compatible with the EHEA qualifications framework;

- to introduce the innovative institutional structure, three-cycle system, new fields of study and training specialists with higher education, that are compatible with the EHEA;

- to design university study programmes according to the Bologna provisions;

- to introduce joint degrees and courses (programmes) for foreign students;

- to develop the NQF for lifelong learning;

- to create the up-to-date instruments of recognition of prior learning (formal, informal, nonformal);

- to implement the Diploma Supplement of the European Union (EU) / Council of Europe (CoE) / the United Nations Educational, Scientific and Cultural Organization (UNESCO format);

- to create the national quality assurance agency for higher education in compliance with the European Standards and Guidelines for Quality Assurance, its full ENQA ( the European 
Association for Quality Assurance in Higher Education) membership and inclusion to the EQAR ( the European Quality Assurance Register for Higher Education);

- to establish the agency for academic recognition and international exchange as the national ENIC (European Network of Information Centers in the European Region) /NARIC (National Academic Recognition Information Centers in the European Union) center;

- to initiate higher education institutions ranking system that would comply with Berlin principles of ranking;

- to increase outward and inward mobility of students and academic and administrative staff of higher education institutions;

- to assure portability of student grants and loans;

- to provide equal access to higher education;

- to prepare research and educational staff, improve their competencies accor' ${ }^{\prime}$ ng to dern requirements with a view to ensuring sustainable development of the country its systo of higher education;

- to develop and introduce new educational standards (curriculum refo $m$ ) with a w the improvement of quality of the content of vocational/professional edy ion a traint, and its adjustment to the needs of employers;

- to create the up-to-date instruments of taking into account 1 or mark lema ads by higher education institutions to facilitate employability of graduates;

- to promote the development of Ukrainian and World cultura qlues, ientation towards the ideals of democracy and humanism essential for the existence an aromelopmen. $/$ civil society.

Thus, the progress of Ukraine in joining the EHE a was substantial/out much remained to be done.

\section{Step 3 - from Leuven/Louvain- la-Neuve (20n9) to Buc. 2012)}

The research methods applied at the age an follows: review of documents and publications; survey of students and nrofesso observation of the educational process and reflection; testing of Bachelors and slas, data c lection.

The meeting took place euy in/Louvan-la-Neuve, Belgium, on April 28-29, 2009. Communiqué of the Confer ... Burogna Process 2020 - The European Higher Education Area in the new decade" s adoptea. he,document mandated that in the decade up to 2020 European higher educa on a vital ontribution to make in realizing a Europe of knowledge that is highly creativa a inn tive. European higher education also faces the major challenge and the ensuing portwnities of sbalization and accelerated technological developments with new providers, lear and new types of learning.

The next $\mathrm{k}$ rovisio were recorded: higher education is being modernized with the adoption thro vele structure including, within national contexts, the possibility of interm diate alificatı s linked to the first cycle and with the adoption of the European Standards and $\mathrm{Gu}$ lin the poten of students from underrepresented groups and by providing adequate conditions for the completion o cir studies; higher education institutions, together with governments, government agencies and 2 mployers shall improve the provision, accessibility and quality of their careers and employment related guidance services to students and alumni; raising initial qualifications as well as maintaining and renewing a skilled workforce through close cooperation between governments, higher education institutions, social partners and students; the higher education institutions should pay particular attention to improving the teaching quality of their study programs at all levels; doctoral programs should provide high quality disciplinary research and increasingly be complemented by inter-disciplinary and inter-sectorial programs; transnational education should be governed by the European Standards and Guidelines for quality assurance; each country should increase mobility, ensure its high quality and diversify its types and scope; improved and enhanced data collection will help monitor progress made in the attainment of the objectives set out in the 
social dimension, employability and mobility agendas, as well as in other policy areas; the transparency tools need to relate closely to the principles of the Bologna Process; greater attention should be paid to seeking new and diversified funding sources and methods [14].

At the Bologna anniversary conference jointly hosted by Austria and Hungary in Budapest and Vienna on March 11-12, 2010 the European Higher Education Area was launched.

\section{The major achievements in Ukraine}

Research and collating the relevant information allows us to state the following. Beginning from London 2007 the following main developments relating to the Bologna process took place in the system of higher education of Ukraine [9, 12]. The order of the Ministry of Edmation and Science of Ukraine on Introduction of the European Credit Transfer System in Her Ec tion Institutions was published in 2009. The Law of Ukraine "On Higher Education" as approv 1 in 2010 (the Bologna provisions and recommendations were partially takep into count). The resolution by the Cabinet of Ministers of Ukraine on the "List of Speci ities Train in Haher Education Institutions at Educational Qualification Levels of Specialist "Mas ", was copted in 2010. The National Qualifications Framework was passed in 201 oopera on between employers, students and higher education institutions was ar leved. L ong learning was becoming one of the important factors in meeting the needs a anging la market. Higher education started to ensure a stronger link between resear teach and learning at all levels. Second cycle programmes became a necessary precond an or the su of linking teaching, learning and research; learning outcomes were under development. Lejrning mobility gradually intensified. Data collection was improved.

The above reflects both the significant achievem of Ukr ine and certain flaw in joining the EHEA.

\section{Main challenges for higher education in Ukrai ?}

A comparison of the Leuven/Lavain-la-h uve Communiqué provisions and our research results gives grounds to assert that the no stage sh wild focus on the following:

- to perfect cooperation betwe gov mments, higher education institutions, students, staff, employers and other stakehol

- to create the appropriate onomic a itions for students to be able to benefit from the study opportunities at all leve s;

- to improve the leaning env ment;

- to support lifelor g learning by ac a uate organizational structures and funding;

- to raise initia ualifi jons as well as maintain and renew a skilled workforce through close cooperation betwo overnm nts, higher education institutions, social partners and students;

- to devel con res and international reference points for subject areas;

- to im rove teachin quality of study programmes at all levels;

- to ino people with research competences;

- to rethin octorar programs;

- to increase 1 lity, to ensure its high quality and to diversify its types and scope;

- to pay greate attention to seeking new and diversified funding sources and methods.

The analysis of the achievements and shortcomings of this period suggests that a large part of the way was passed, but there still were a lot of problems.

\section{Step 4 - from Bucharest (2012) to Yerevan (2015)}

The research methods applied at the stage are as follows: review of documents and publications; survey of students, $\mathrm{PhD}$ students and professors; observation of the educational process and reflection; testing of Bachelors, Masters and PhD students, data collection; overview of the official sites of Ukrainian universities. 
The next Ministerial Meeting took place in Bucharest, on 26 and 27 April 2012. The Ministers took stock of the achievements of the Bologna Process and agreed on the future priorities of the EHEA. In the Bucharest Communiqué "Making the Most of Our Potential: Consolidating the European Higher Education Area" [15] the following was stated: higher education structures in Europe are now more compatible and comparable; quality assurance systems contribute to building trust; higher education qualifications are more recognizable across borders and participation in higher education has widened.

\section{The following key priorities for action by 2015 are set out:}

- to establish conditions that foster student-centered learning, innovative teaching metho and a supportive and inspiring working and learning environment, while continu ig to olve students and staff in governance structures at all levels;

- to allow EQAR-registered (the European Quality Assurance Register fo Hig Educa on) quality assurance agencies to perform their activities across the EHE, while co, vin, with national requirements;

- to work to enhance employability, lifelong learning, problem-soly g a entrepre eurial skills through improved cooperation with employers, especially in $t^{\prime}$ e develo ent if educational programs;

- to ensure that qualifications frameworks, ECTS and Diploma upplo nt implementation is based on learning outcomes;

- to invite countries that cannot finalize the implemen tion of national q $_{4}$ ualifications frameworks compatible with QF-EHEA by the end of 2012 to double theif efforts and submit a revised roadmap for this task;

- to implement the recommendations of the ctrategy

towards full portability of national grants and lo

- to review national legislation to fully comp y ltis Lisbon Recognition Convention and promote the use of the EAR-manual to ance re gnition practices;

- to encourage knowledge-based all ance the El $\mathrm{F}$, focusing on research and technology.

\section{The major achievements in V...in. ejoresptember)}

Studies have sho n main ach ovements of Ukraine. Some professional standards are designed [8]. Law o Higher Education" was approved in July 2014 (the Bologna provisions and rec ommendations a been taken into account) [16]. A number of higher education institutions war duce 50 universities). The resolution on information disclosure of the higher education institut activiti was adopted in February 2015. The recommendations for 2015/16 academic currio de elopment were designed in March 2015. Forms of the higher education docum nts W e appro $\mathfrak{A}$ in March 2015. Instruments for graduates employment were refined in Aprif Applican. vaining was adopted in April 2015. Diploma Supplement forms were adopted in May 2015. Institu 1 Education Analytics and Institute of Educational Content Modernization were created in June 2015. The decision on improving quality of the learning outcomes external independent assessment was taken in June 2015. European model Diploma Supplement was issued to all graduates in July 2015. The resolution about laying out the theses and the official opponents reviews on the university sites was accepted (August 2015).

All of the above materials are freely available on the Ministry of Education and Science of Ukraine official website [12].

A list of the documents presented shows a significant intensification of efforts of Ukraine in joining the EHEA. 


\section{CONCLUSION}

Over the last decade, Ukraine has passed a complicated and responsible way to join the EHEA. Much has been done. Something succeeded, something needs to be improved and implemented. According to the Yerevan Communiqué (May 2015) by 2020 Ukraine should focus on the following key issues: enhancing the quality and relevance of learning and teaching; fostering the employability of graduates throughout their working lives; making the systems more inclusive; implementing agreed structural reforms [17].

To this we add that, from our point of view, special attention should be paid to the following:

- to harmonize the relevant national documents with the revised Standards and Guidelines for Quality Assurance in the European Higher Education Area (ESG) [18]; the European Approach for Quality Assurance of Joint Programs [19] and the revised ECTS Users' Guide [201_fficial EHEA document.

\section{References}

[1] Zhuravs'kyj V.S. Bolons'kyj protses [Tekst]: holovni pryntsypy vk' Zhen ${ }^{1}$ V Yey opejs'kyj prostir vyschoi osvity / V.S. Zhuravs'kyj, M.Z. Zghurovs'kyj K. JTs , ydavnytstvo „Politekhnika”, 2003. - 200 s.; Vyscha osvita Ukrainy i Bolons'k protses: 1 hay nyj posibnyk / Za redaktsiieiu V.H Kremenia. Avtors'kyj kolektyv: M.F st , Ya.Ya Boliubash, V.D. Shynkaruk, V.V. Hrubinko, 1.1. Babyn. - Ternopil' : Navc q a kn - Bohdan , 2004. - 34 s. (Ukrainian)

[2] Sorbonne Declaration (1998). Information on http://www.ond.vlaanderen.be/hogeronderwijs/bologna documents/MDC/SORBONNE_DECLARATION1.pdf

[3] Bologna Declaration (1999). Information bologna/ documents/ MDC/BOLOGNA_DECL, RA' 1 , .pdf

[4] Prague Communiqué "Towards tropean Higher Education Area" (2001). Information on http://www.ond.vlaanderen.be/hor ronde vijs/bolo /a/documents/MDC/PRAGUE_COMMUNIQ UE.pdf

[5] Berlin Communiqué "p glizing th uropean Higher Education Area" (2003). Information on http://www.ond.vlaande en. ogeronde $/ \mathrm{jj} /$ /bologna/documents/MDC/Berlin_Communique1.pdf [6] Pro vyschu osvit. Zakon Uk v/Uriadovyj kur'ier. - 15 travnia. - 2002. - № 86. (Ukrainian) [7] Prohrama ovede ja pedahohichnoho eksperymentu schodo vprovadzhennia kredytnomodul'noi systen, ${ }^{\prime}$ anizat i navchal'noho protsesu u vyschykh navchal'nykh zakladakh III-IV rivniv akr-atsii Jakaz MON Ukrainy vid 23.01.2004 r. № 48. (Ukrainian)Information on http://o a.mo ov.ua/

[8] Pro akovo-tekhnichnu diial'nist' : Zakon Ukrainy // Vidomosti Verkhovnoi Rady Ukrainy. - 92 - № 12. (Ukrainian)

[9] Bologna rocess. Ukraine national reports 2005, 2007, 2009, 2012. Information on http://www. ehea.info/article-details.aspx?ArticleId=86

[10] Bergen Communiqué “The European Higher Education Area - Achieving the Goals" (2005). Information on http://www.ond.vlaanderen.be/hogeronderwijs/bologna/documents /MDC/050520_ Bergen_Communique1.pdf

[11] Koval, I. Problems of reforming the higher education in Ukraine with regard to the Bologna Process. Foundazione-Delbianco (2007). Information on http://www.fondazione-delbianco.org/seminari/progetti_prof/progview.asp?id=297

[12] Information on http://old.mon.gov.ua/ua/about-ministry/normative/; http://osvita.ua/legislation/ 
[13] London Communiqué "Towards the European Higher Education Area: responding to challenges in a globalized world" (2007). Information on http://www.ond.vlaanderen.be/ hogeronderwijs/bologna/documents/MDC/London_Communique18May2007.pdf

[14] Leuven/Louvain-la-Neuve Communiqué "The Bologna Process 2020 - The European Higher Education Area in the new decade" (2009). Information on http://www.ond.vlaanderen.be/ hogeronderwijs/ bologna /conference/documents/Leuven_Louvain-la Neuve_Communiqué_ April_2009.pdf

[15] Bucharest Communiqué "Making the Most of Our Potential: Consolidating the European Higher Education Area"(2012). Information on http://www.ehea.info/Uploads/\%281\%29/Bucharest\%20Communique\%202012\%281\%20 ndf

[16] Law of Ukraine On Higher Education (2014). Information on http://www.erasmusplus.org.ua/2014-05-30-14-56-19/prezentatsii/category/3-ma natsionalnoi-komandy-ekspertiv-shchodo-zaprovadzhennia-instrumentiv-bolo koho tsesu, $\mathrm{ml}$ [17] Yerevan Communiqué (2015). Information on http://www.ehea.inf/Uplo is/Sub cdFiles/ 5_2015/1 12705.pdf

[18] Standards and Guidelines for Quality Assurance in the F ropean A or Fucation Area. Information on

https://www.eqar.eu/fileadmin/documents/e4/ESG_-_draft loreso vy_BFUG.pdf

[19] The European Approach for Quality Assurar of Joint Pr srams. Information on https://eqar.eu/fileadmin/documents/bologna/02_Euro ean_Approach_QA_of_Joint_Programme s_v1_0.pdf

[20] ECTS Users' Guide - 2015. Information o http://ec._u/education/library/publications/ 2015 /ects-users-guide

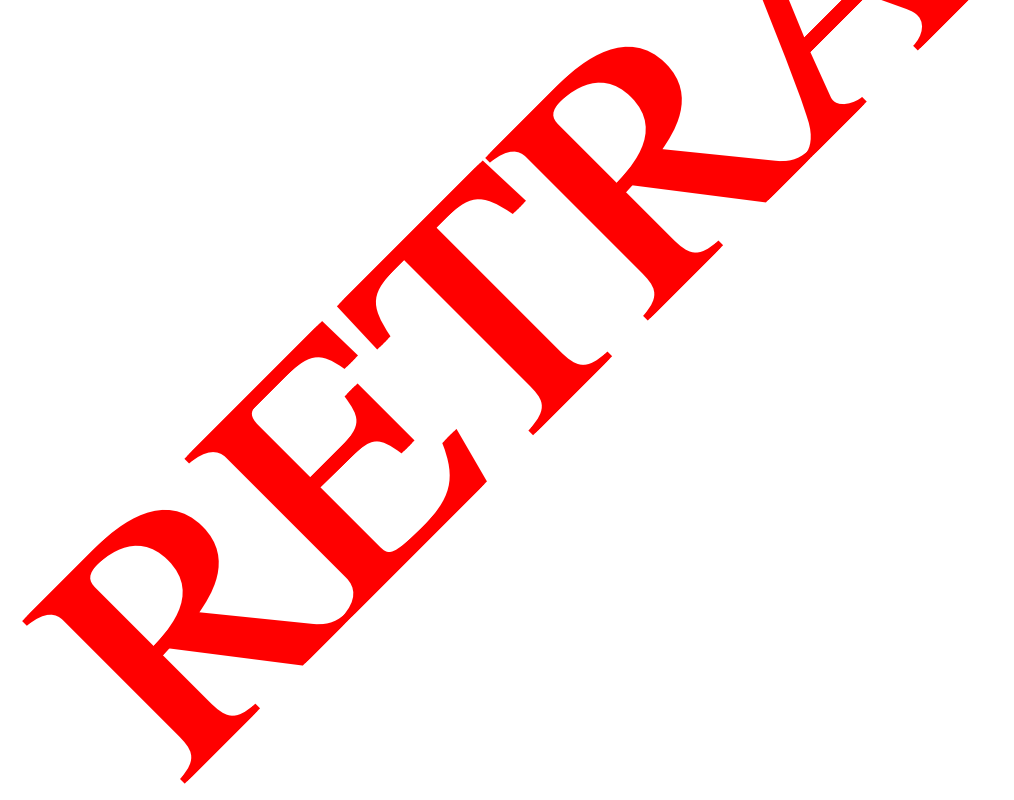

